Board of Governors of the Federal Reserve System

International Finance Discussion Papers

Number 821

October 2004

Global Financial Integration: A Collection of New Research

An introduction by Mark Carey to research papers by

John Ammer

Carol C. Bertaut

Fang Cai

Mark Carey

Jon Faust

Sara B. Holland

Linda S. Kole

Greg Nini

John H. Rogers

David C. Smith

Charles P. Thomas

Shing-Yi B. Wang

Francis E. Warnock

Jon Wongswan

Jonathan Wright

NOTE: International Finance Discussion Papers are preliminary materials circulated to stimulate discussion and critical comment. References in publications to International Finance Discussion Papers (other than an acknowledgment that the writer has had access to unpublished material) should be cleared with the author or authors. Recent IFDPs are available on the Web at www.federalreserve.gov/pubs/ifdp/. 


\title{
Global Financial Integration: A Collection of New Research
}

\author{
Introduction by Mark Carey to research papers by: \\ John Ammer \\ Carol C. Bertaut \\ Fang Cai \\ Mark Carey \\ Jon Faust \\ Sara B. Holland \\ Linda S. Kole \\ Greg Nini \\ John H. Rogers \\ David C. Smith \\ Charles P. Thomas \\ Shing-Yi B. Wang \\ Francis E. Warnock \\ Jon Wongswan \\ Jonathan Wright
}

\begin{abstract}
This introductory note summarizes and draws together the work reported in eight research papers written by staff economists of the Board's Division of International Finance as part of a project on global financial integration. The eight papers are also International Finance Discussion Papers, the numbers of which are specified on the table of contents that appears herein. When viewing this introduction online, the paper titles appearing on the table-of-contents page are web links that may be used to navigate directly to each paper's online file. All recent IFDPs are available on the Web at www.federalreserve.gov/pubs/ifdp/.
\end{abstract}

Keywords: globalization, international portfolio allocation, home bias, equities, bonds, loans, exchange rates, emerging market finance.

JEL Codes: G15, F36, G11, G12, G2, G3, F21, F31

All the papers in this collection will be revised as they go through journal publication processes and thus should be viewed as preliminary work being circulated to stimulate discussion. The views in the introduction and in the papers discussed herein are solely the responsibility of the authors and should not be interpreted as reflecting the views of the Board of Governors of the Federal Reserve System or of any other person associated with the Federal Reserve System. The views in this introduction are solely those of Mark Carey and are not necessarily those of the authors of the papers. Contact information: mark.carey@frb.gov, 202-452-2784. 


\section{Table of Contents: Papers Introduced by This Note}

IFDP

Number Title When viewing this page online, clicking on a title will retrieve the paper. Click the Back button of your internet browser to return to this page.*

$821 \quad$ Introduction

Mark Carey

819 What makes investors over or underweight? Explaining international appetites for foreign equities

Carol C. Bertaut and Linda S. Kole

815 Look at me now: The role of cross-listing in attracting U.S. shareholders

John Ammer, Sara B. Holland, David C. Smith, and Francis E. Warnock

$793 \quad$ International diversification at home and abroad

Fang Cai and Francis E. Warnock

818 Cash flows and discount rates, industry and country effects, and co-movement in stock returns

John Ammer and Jon Wongswan

817 The performance of international portfolios

Charles P. Thomas, Francis E. Warnock, and Jon Wongswan

$784 \quad$ The high-frequency response of exchange rates and interest rates to macroeconomic announcements

Jon Faust, John H. Rogers, Shing-Yi B. Wang, and Jonathan H. Wright

$820 \quad$ The value of financial intermediaries: Empirical evidence from syndicated loans to emerging -market borrowers

Greg Nini

$813 \quad$ Is the corporate loan market globally integrated? A pricing puzzle

Mark Carey and Greg Nini

* Single hard copies of IFDPs may be obtained by request from:

Publications, International Finance Discussion Papers

Mail Stop 127

Federal Reserve Board

Washington, DC 20551 USA 
International financial integration is a subject of perennial interest to academics and policymakers. The extent of integration, whether measured by price differences or comovements, by responses to information arrivals, or by the fit of models of capital flows and portfolio allocations, provides clues about the realism of models and about the role of barriers and frictions in market outcomes.

Barriers to integration are not limited to capital controls or other laws and regulations. Barriers also include factors such as transaction costs and information asymmetries. Reducing such barriers and frictions is usually in the interest of all entities except those that enjoy local market power as a result of the frictions. However, the relative importance of different frictions and the best way to reduce them are not well understood. Thus, research aids policymaking and financial integration is likely to continue to be an active area of research. Recent surveys of such research include Adam et al. (2002), Eichengreen (2001), Gaspar, Hartmann and Sleijpen (2003), and Karolyi and Stulz (2002). ${ }^{1}$

Some staff members of the Division of International Finance of the Federal Reserve Board recently chose to undertake a project on global financial integration, producing eight new empirical research papers which are introduced by this note. The papers contribute to a variety of literatures, including those focused on capital flows (especially the home bias phenomenon), financial intermediation, performance measurement, asset pricing, and monetary policy transmission. Most of the papers both measure the extent of integration and also the determinants of integration. Some focus on prices, others on quantities. ${ }^{2}$

Many of the themes that unite modern research in finance---risk, information, transaction costs---appear in the papers, particularly the importance of information asymmetries. The papers contribute to the picture, already sketched by earlier research, of a world in which some markets are integrated in the sense of rapid and coherent responses of prices to common

\footnotetext{
${ }^{1}$ Policymakers' views about the net benefits of globalization may influence their views about the aggressiveness with which financial integration should be promoted, but even opponents of globalization are likely to favor at least some measures promoting financial integration. Proponents of financial integration often emphasize that it improves risk sharing, promotes competition, and promotes more efficient allocation of capital and thus more productive investment and more rapid economic growth. Opponents note that greater integration may be associated with stronger and more rapid transmission of shocks originating in one market, country or region to others and with more volatile market prices. Prasad, Rogoff, Wei and Kose (2003) empirically examine many of these hypotheses.

${ }^{2}$ Other papers not in this collection, but related to financial integration, have been produced by Board staff during 2003 and 2004, including International Finance Discussion Papers 753, 755, 757, 759, 769-771, 775 and 778 and Finance and Economics Discussion Series papers 2003-47 and 2004-26.
} 
information arrivals. However, in other markets, information asymmetries and other frictions appear to contribute to material departures from full-integration benchmarks. Perhaps the most important message of the papers as a group is that the key frictions hampering financial integration are not simple or already well-understood. Considerable further research is needed to strengthen understanding of how best to pursue financial integration.

Six of the eight papers at least touch upon the home bias puzzle and three focus on it. Much of the empirical literature on home bias has examined the behavior of U.S. investors, who underweight foreign equities and bonds in their portfolios relative to the shares of such instruments in the world market, thus apparently violating the recommendations of Markowitz portfolio theory (French and Poterba 1991). A few studies of behavior in other countries have shown that home bias is not a purely U.S. phenomenon(e.g. Kang and Stulz 1997), but Bertaut and Kole's paper in this collection offers a geographically comprehensive study. They examine country weightings in the aggregate equity portfolios of 31 investor countries, finding that home bias is pervasive. Strikingly, in the portfolios of non-U.S. investors, home bias is more pronounced against the U.S. than against most other countries, and the mitigating effect of level I and II ADR listings on U.S. exchanges is somewhat weaker than a listing in London. These are important findings because information asymmetries and fear of expropriation are often thought to be an important source of investors' reluctance to invest abroad. The U.S. is often thought to offer relatively good transparency, corporate governance, and legal protection for foreign investors. Thus, one might expect a smaller underweight of U.S. equities in non-U.S. investors' portfolios, and a larger effect of ADRs, the opposite of Bertaut and Kole's findings. Their results do not imply that information and governance are unimportant, but do cast doubt on assumptions that any transparency, governance, or legal advantages of investing in the U.S. dominate other factors, such as possible information advantages that foreign investors have in "nearby" markets. Other results help the reader make sense of the relative unpopularity of the U.S.: Regional and political ties matter, as do physical distance, volume of trade, and other measures. The U.S. is relatively "far away" from much of the rest of the world by such measures. Bertaut and Kole's study suggests that a full explanation of home bias is not likely to involve only one or two mechanisms or one or two dimensions of information. Though the aggregate nature of their data limits their ability to test hypotheses, the new and useful stylized facts in their paper are likely to help shape future research. 
The study by Ammer, Holland, Smith and Warnock is also pertinent to home bias. The authors begin byjointly modeling a foreign firm's decision to cross-list and U.S. investors' decision to hold the firm's equity, using individualequity data for essentially the universe of U.S. investors' foreign holdings in 1997. They find that among the vast majority of non-U.S. firms -those that are not cross-listed -- U.S. investors are attracted by financial transparency and information availability. They also document the first direct evidence that cross-country tax distortions contribute to U.S. investors' home bias. The most striking findings in Ammer, Holland, Smith and Warnock concern the magnitude and determinants of what they term the cross-listing effect, the increase in U.S. holdings that a cross-listing spurs. Selectivity and endogeneity issues plague prior work in this literature, and the authors vigorously attack these problems. The y use several different econometric techniques that account for such endogeneity and each points to the same conclusion: Foreign firms that cross-list would indeed have attracted more U.S. investment had they not cross-listed, but even accounting for the endogeneity, a crosslisting still roughly doubles a firm's weight in U.S. portfolios.

But why? The authors confront three possible explanations for the dramatic effect of a U.S. listing on portfolio weights: that cross-listed firms are simply more visible to U.S. investors; that such firms must to some extent abide by U.S. corporate governance norms and securities laws; and that information asymmetries are less severe for cross-listed than for other foreign firms, in part because they conform to many U.S. disclosure requirements. Drawing upon estimates both from their structural model and from a non-parametric approach, Ammer, Holland, Smith, and Warnock find support for the information hypothesis. For example, firms with weak disclosure at home enjoy a larger listing effect when they submit to U.S. disclosure requirements. A possible direction for future work would be to reconcile the lack of support for familiarity and governance explanations with findings of previous studies that good governance matters to investors.

Factor models are the workhorses of financial asset pricing, and viewed through their lens, the rejection of portfolio theory posed by home bias is not so much a problem of countryweights that are too small, but rather a (presumed) problem of inadequate exposure to foreign factors. If the profitability of firms' economic activity in different parts of the world is not perfectly correlated, exposing an equity portfolio to many foreign factors can improve portfolio performance in risk-reward space. Cai and Warnock provide evidence that, in factor space, the 
home bias of U.S. investors is quite a bit smaller than in country-weight space. U.S. institutional investors favor U.S. multinational firms and, because the activities of multinationals are geographically diverse, the returns to their equities are driven in part by foreign factors, so U.S. investors get exposure to foreign factors by investing in firms that are headquartered in the U.S. Moreover, foreign investors in U.S. equities also favor multinationals over purely domestic U.S. firms, suggesting that, by investing in the U.S., foreign investors somewhat reduce the degree to which they are underweight non-U.S. factors. Although considerable home bias remains even in factor space, Cai and Warnock's paper reminds us that it is important to look beyond country weights.

Ammer and Wongswan focus directly on the importance of a multifactor view. For the first time, they draw together a literature that decomposes equity return co-movements across countries into industry and country effects (e.g. Heston and Rouwenhorst 1994), and a literature that decomposes co- movements into cash flow and discount rate effects (Ammer and Mei 1996). They find that global, country and industry factors all are important, and not only for cash flow, but also for discount rates. The discount rate finding characterizes the world as being considerably, but not completely, financially integrated in the sense of pricing kernels. A finding that only country factors matter for discount rates would imply segmentation in the pricing of equity cash flow risk along national boundaries, whereas no role for country factors (only global and sectoral factors) would imply strong integration of markets for such risk. In fact, country factors account for an eighth to a quarter of the variance of estimated discount rates, whereas global and sectoral factors account for half to three-quarters of such variance. National factors are a bit more important for cash flow, but global and sectoral factors again are more important. Though Ammer and Wongswan do not touch upon home bias, their results suggest that sectoral diversification of equity portfolios may be at least as important as geographic diversification. Thus, future research on home bias might examine differences in the sector exposure of investors in different countries.

It would be natural for investors to underweight foreign securities if their investments in such securities offer smaller average returns than domestic investments. As noted previously, reasons that foreigners might suffer a "negative alpha" relative to locals include extra cost or difficulty in obtaining information or in defending legal claims. Thomas, Warnock and Wongswan examine the performance of U.S. investors' international bond and equity portfolios 
relative to U.S. assets and relative to global benchmark indexes over a long time period. A striking finding is that movements in dollar exchange rates dominate the relative performance of U.S. and foreign portfolios: Foreign assets outperform when the dollar depreciates and underperform when the dollar appreciates. Because dollar exchange rate move ments have been dominated by large, long-duration swings since the dollar floated in 1973, one implication of Thomas, Warnock and Wongswan's work is that long sample periods and careful attention to exchange rate factors are essential to global performance studies. Another implication is that exchange rate risk may be a material cause of home bias. If investors are particularly unwilling to bear low-frequency, large-amplitude risks, they may be particularly reluctant to hold large volumes of assets denominated in currencies that do not move closely with the currency in which they consume.

Of course, exchange rate risk can be hedged, and Thomas Warnock and Wongswan shed some light on the performance of hedged portfolios by examining how U.S. investors' foreign equity and foreign bond portfolios performed relative to global indexes. They find no evidence of underperformance, and some evidence of outperformance for equities, although such outperformance can be ascribed to efficient use of publicly available information. Overall, their evidence provides little support for an explanation of home bias that relies on subnormal average returns earned by non-local investors.

It would have been particularly surprising if Thomas, Warnock and Wongswan had found evidence of abnormal performance of U.S. investors' bond portfolios. Macroeconomic factors are the dominant drivers of bond portfolio returns and macroeconomic information is largely public. Faust, Rogers, Wang and Wright's high- frequency analysis of the impact of U.S. macroeconomic announcements on interest rates and foreign exchange rates confirms this intuition. During their sample period, which begins in 1987, anyone with access to electronic trading screens or information services could see information releases like the U.S. unemployment rate or GDP in real time. It is comforting that such releases engender almost instantaneous price responses in non-U.S. as well as U.S. markets. Earlier papers found this result in individual markets, but Faust, Rogers and Wright find it in several major markets. Their paper focuses on characterizing market reactions through the lens of theories of uncovered interest-parity (UIP). While they find that market responses are coherent with the theory, such coherence will not give much comfort to advocates of UIP models because coherence requires 
either that strong U.S. macroeconomic news lowers the risk premium on non-U.S. assets or that foreign exchange rates do not follow a random walk. Overall Faust, Rogers, Wang and Wright's paper sets a kind of information benchmark for students of financial integration: International differences in the processing of easily available public information are not likely to be material, so information-based stories must focus on information that is not completely public.

Among all firms, it is natural to expect non-public information to be most material for those domiciled in emerging markets. Nini finds striking evidence of local-bank expertise in the screening and monitoring of emerging-market firms, that such expertise matters for debt pricing, and that international banks are able to form coalitions that exploit the expertise. Nini examines syndicated loans to emerging-market firms, finding that local banks have a greater propensity to participate in loans to risky firms than to safe firms (risky firms are likely to pose greater problems of asymmetric information). Moreover, even after controlling for selection effects, the presence of a local lender in a lending syndicate is associated with econo mically significantly smaller interest rate spreads paid by the borrower. That is, the borrower and the foreign banks in a syndicate are able to benefit from the expertise of the local bank. Nini's paper is novel evidence of the importance of screening and monitoring as emphasized in the literature on financial intermediation. It is also evidence that screening and monitoring expertise is not necessarily lodged in the "lead" bank in a syndicate, as has been assumed in the literature to date, e.g. Dennis and Mullineaux (2000) (foreign banks are usually designated as the lead bank in emerging-market syndicates). ${ }^{3}$

Carey and Nini present evidence that the syndicated loan market is not completely globally integrated. On the one hand, most factors thought to be material to loan pricing are significant in their simple pricing models, and factor loadings appear similar in the U.S. and European markets. For example, public information about borrower credit risk is priced similarly. However, the loan portfolios of banks in each nation appear to display considerable home bias in terms of borrower country weights. Moreover, Carey and Nini find that even in the presence of an extensive array of controls, interest rate spreads are at least 20 percent smaller in the European market than in the U.S. market for similar loans to similar borrowers. There has been no discernable trend in this difference over the past decade. Such a large price difference is

\footnotetext{
${ }^{3}$ Though it is not the focus of their paper, Carey and Nini find little evidence of an effect of localbank participation on loan spreads in the European loan market, consistent with the common assumption that problems of asymmetric information and moral hazard are more severe in emerging markets.
} 
surprising because both borrowers and lenders in the U.S. and European syndicated loan markets are large and sophisticated entities and all the borrowers in the sample of loans that Carey and Nini use to study pricing are rated. One would think that information asymmetries and other frictions would be small for such borrowers. Home bias appears to play a role in maintaining the price difference, but is not the whole story behind Carey and Nini's pricing puzzle because risk could be priced similarly even under autarky.

Taken together, the papers in this collection add materially to our understanding, but also suggest that much work remains to be done in pursuit of understanding of international finance and the extent to which financial markets are integrated across nations. 


\section{References}

Adam, Klaus, Tullio Jappelli, Annamaria Menichini, Mario Padula, and Marco Pagano, 2002, "Anayze, compare and apply alternative indicators and monitoring methodologies to measure the evolution of capital market integration in the European Union," working paper, University of Salerno.

Dennis, Steven A., and Donald J. Mullineaux, 2000, Syndicated loans, Journal of Financial Intermediation 9, 404-426.

Eichengreen, Barry, 2001, Capital account liberalization: What do cross-country studies tell us? World Bank Economic Review 15(3), 341-365.

Frankel, Jeffery, 1992, Measuring international capital mobility: A review, American Economic Review 82:2.

French, Kenneth R., and James M. Poterba, 1991, Investor diversification and international equity markets, American Economic Review 81, 222-226.

Gaspar, Vitor, Philipp Hartmann and Olaf Sleijpen, 2003, "Introduction," in The transformation of the European financial system (Frankfurt: European Central Bank), 7-30.

Kang, Jun-Koo, and Rene M. Stulz, 1997, Why is there home bias? An analysis of foreign portfolio equity ownership in Japan, Journal of Financial Economics 46, 3-28.

Karolyi, Andrew and Rene Stulz, 2002, “Are financial assets priced locally or globally?” NBER working paper 8994.

Prasad, Eswar S., Kenneth Rogoff, Shang-Jin Wei and M. Ayhan Kose, 2003, Effect of financial integration on developing countries: Some empirical evidence, IMF Occasional Paper 220 (Washington: International Monetary Fund). 